\title{
Regional expansion of emerging market SMEs: the roles of domestic market environmental uncertainty and international alliance partner diversity
}

\author{
Nadia Zahoor ${ }^{1}$ (D) Francis Donbesuur ${ }^{2} \cdot$ Arinze Christian Nwoba $^{3} \cdot$ Huda Khan $^{4}$
}

Accepted: 6 November 2021 / Published online: 22 November 2021

(c) The Author(s) 2021

\begin{abstract}
This study develops and tests a framework of the effect of domestic market environmental uncertainty on international alliance partner diversity (IAPD) and the effect of IAPD on small and medium-sized enterprises' (SMEs') regional expansion. Leveraging primary data from a sample of 232 Pakistani SMEs, the findings indicate that domestic market dynamism and technological dynamism drive SMEs to engage in IAPD. The analysis further reveals that IAPD improves SMEs' regional expansion, and particularly so at higher levels of cross-cultural knowledge absorption. The research and practical implications of these findings are discussed.
\end{abstract}

Keywords Domestic market uncertainty · International alliance partner diversity · Cross-cultural knowledge absorption · Regional expansion · Emerging markets · Pakistan

Nadia Zahoor

nadia.zahoor@strath.ac.uk

Francis Donbesuur

f.donbesuur@lboro.ac.uk

Arinze Christian Nwoba

A.c.nwoba@greenwich.ac.uk

Huda Khan

huda.khan@abdn.ac.uk

1 University of Strathclyde, Glasgow G1 1XQ, UK

2 Loughborough University, Loughborough LE11 3TT, UK

3 University of Greenwich, London SE10 9LS, UK

4 University of Aberdeen, King's College, Aberdeen AB24 3FX, UK 


\section{Introduction}

The exploitation of international business opportunities has become a viable firm strategy to cope with the increased pressure of globalization and competitiveness. Accordingly, scholars and practitioners have become interested in understanding the regional and global expansion strategies of small and medium-sized enterprises (SMEs) (Boso et al., 2017; Mueller-Using et al., 2020). Chetty and Campbell-Hunt's (2003) view on the regional expansion of SMEs challenged the implicit notion of globally competing SMEs due to their resource deficiencies and lack of capabilities (Iurkov \& Benito, 2018). Consequently, recent studies have emphasized the need for research that seeks to explore the determinants of SMEs' expansion within and beyond close and familiar environments, essentially regional environments, near their home markets (e.g., Boso et al., 2017; Pisani et al., 2017; Stouraitis et al., 2017). Due to the initiation and coordination cost of global expansion, its disadvantage can offset its potential benefits for resourceconstrained SMEs (Boso et al., 2017), hence there are significant implications for the growth and competitiveness of SMEs that choose to internationalize regionally-especially those that operate within resource-constrained and institutionally adverse economies (cf. Khan et al., 2018). Thus, this study builds on the existing research to extend our current understanding of the phenomenon of regional expansion of SMEs. Herein, we define regional expansion as the degree of extensiveness of international activities within regional markets (Zahra, 2020). It also explains the diversity of a firm's international activities within the chosen regional market, such as number of regional markets and diversity of exports.

Research in the international business literature suggests several determinants of regional expansion including organizational strategy, processes, structures, and capabilities (e.g., Martineau \& Pastoriza, 2016). Within the international entrepreneurship domain, specific attention has been devoted to international strategic alliance-a cooperative arrangement between firms across country borders (Gulati, 1998) — as a potential driver of regional expansion (Andersson et al., 2013). While domestic alliances can provide access to critical information for business opportunities (Idris \& Saridakis, 2018; Iurkov \& Benito, 2020), extant literature suggests that international strategic alliances and networks are beneficial for SME regional expansion as partners from different national backgrounds can provide different resources, fine-grained knowledge, and innovative ideas (Ho et al., 2019; Nakos et al., 2014). They can also help the resource-constrained SMEs to develop capabilities and provide a basis for innovation, strategic renewal, and global competitiveness (Shijaku et al., 2020). Furthermore, the complex and synergistic interactions among international partners provide SMEs with easier access to information about proximate markets and to overcome the liabilities of smallness, newness, and foreignness (Li et al., 2013; Zahoor \& Lew, 2021). Recently, a small but growing number of studies have examined the benefits of network attributes, particularly international alliance partner diversity-IAPDto firm success (Musteen et al., 2014a; Pesch \& Bouncken, 2018). IAPD refers to the degree of heterogeneity/variety in the types of international alliance partners, 
where types of partners include customers, suppliers, consultants, and research institutions (Garcia Martinez et al., 2017; Hagedoorn et al., 2018; Mohr et al., 2016). Diverse international partners are advantageous to SMEs as they offer a variety of knowledge which might be difficult to obtain from purely domestic alliances, and thus give more valuable opportunities for learning (Vlaisavljevic et al., 2016). Indeed, it is difficult for a single partner to provide all the resources and specialized knowledge necessary for SMEs to succeed in today's dynamic and complex environments. Thus, SMEs need to leverage a set of diverse international partners, customers, suppliers, consultants, and research institutions, to achieve their aim of regional expansion.

Despite the undeniable advantages of IAPD, three salient gaps remain in the extant alliance-international business literature. First, there is a limited understanding on the environmental factors that drive SMEs to engage with their IAPDs. Thus, the strategic choice perspective contends that strategic actions of managers are guided by the nature of the organizational environment (Child, 1972, 1997), such that these choices may be determined by the nature and characteristics of the environment in which firms operate. This is also consistent with the relational view (Dyer \& Singh, 1998; Dyer et al., 2018) that echoes the relevance of environmental uncertainty for alliance relationship building. Accordingly, the diversity of international alliance partners is a strategic action, but research has overlooked the role of different dimensions of domestic environmental uncertainty to guide this strategic action (Hagedoorn et al., 2018). To address this gap, we investigate the role of domestic environmental uncertainty-consisting of competitive intensity; technological dynamism; and market dynamism - in shaping the IAPD of SMEs originating from an emerging market-Pakistan.

Second, extant research suggests that IAPD does matter for global expansion of SMEs (Musteen et al., 2014a). However, due to differences in regional and global markets (Verbeke \& Asmussen, 2016), it is not possible for all firms to equally benefit from diverse international partners (Ardito et al., 2019). In this sense, alliance literature suggests that conscious managerial efforts can promote the advantages of diverse partners (Vlaisavljevic et al., 2016). However, the dynamic capability view suggests (Teece et al., 2016) that it is not only important to consider managerial efforts (i.e., governance mechanisms), but also to pay attention to knowledge absorption capability to support acquisition and transfer of knowledge across borders in dynamic environments (cf. Cohen \& Levinthal, 1990; Zahra \& George, 2002). Accordingly, by integrating insights from the dynamic capability view and knowledge management literature (Teece et al., 2016), we argue that some SMEs are able to exploit IAPD for regional expansion due to their ability to absorb cross-cultural knowledge. Specifically, we explore cross-cultural knowledge absorption capability ${ }^{1}$ that may moderate the IAPD-regional expansion relationship.

Third, the majority of research on alliance diversity and regional expansion is conducted on large firms from developed countries (Demirbag et al., 2020;

\footnotetext{
${ }^{1}$ It is the capability of a firm to create, transfer, integrate, and apply knowledge from diverse international alliance partners (Zhang et al., 2018).
} 
Hagedoorn et al., 2018). Scholars highlight that the evidence for firms from large, advanced economies can hardly be applicable to developing market SMEs, which often face significant domestic institutional hardships (Deng \& Zhang, 2018; Wu \& Deng, 2020). Broadly speaking, environmental uncertainty is a major characteristic of business environments in developing countries. Therefore, nations in Asia such as Pakistan attempt to overcome domestic environmental uncertainty by making a greater leap forward to international markets (Adomako et al., 2019; Khan \& Lew, 2018), and firms based in such markets benefit from global networks for their innovation (cf. Khan et al., 2018). Specifically, Pakistani SMEs face serious environmental challenges, which develops their strategic agility (i.e., dynamic capability) by quickly adapting and responding to dynamic changes and implementing actions to control domestic environmental uncertainty (Khan, 2020). Strategic agility can help Pakistani SMEs to continuously scan the environment for upcoming opportunities and improve their market-seeking regional expansion (Ahammad et al., 2021). However, despite possessing strategic agility (Irfan et al., 2019; Shin et al., 2015), Pakistani SMEs are generally resource deficit and carry the legacy of newness in international markets (Irfan et al., 2019; Khan \& Lew, 2018). As such, they need to pursue strategies that can help them to overcome domestic environmental uncertainty and at the same time exploit the opportunities in the regional markets (Zahoor et al., 2020). We investigate this issue by arguing that agile Pakistani SMEs can swiftly respond to domestic environmental uncertainty by pursuing IAPD, which, in turn, enhances their regional expansion.

In sum, we take a cue from the tenets of the relational view and dynamic capability view, to examine the following research questions: (1) what are the effects of domestic environmental uncertainty dimensions (i.e., competitive intensity, technological dynamism, and market dynamism) on SMEs' pursuit of IAPD?; (2) what is the relationship between IAPD and SMEs' regional expansion; and (3) how does this relationship between IAPD and SMEs' regional expansion differ under different levels of cross-cultural knowledge absorption? We answer these research questions by leveraging unique survey data of 232 Pakistani SMEs; in doing so, the study provides several important contributions to the extant literature.

First, our study contributes to the relational view and international alliance literature by offering further insights on the role of domestic environmental uncertainty in shaping IAPD. Although existing research has studied the role of environmental uncertainty in strategic alliances (Zahoor et al., 2021), we extend the current discourse by considering the role of different dimensions of domestic environmental uncertainty for IAPD in SMEs (Dorobantu et al., 2019). Second, our study extends the international alliance and international business literature by considering the role of IAPD in regional expansion of resource-constrained SMEs originating from emerging markets. Specifically, we argue that IAPD provides access to regional market specific knowledge and information, thus supporting the efforts of SMEs' regional expansion. Third, the study contributes to the dynamic capability view and the existing international alliance literature by investigating the moderating effect of cross-cultural knowledge absorption on the relationship between IAPD and regional expansion of SMEs. Fourth, we extend the domain of relational view and dynamic capability view by testing our framework on a sample of Pakistani SMEs. Although 
Pakistan shares some similar institutional conditions with other neighboring countries, such as China and India (Khan \& Lew, 2018), Pakistani SMEs are more agile and resilient, given the fragile institutional conditions they encounter compared to their counterparts based in China and India. This can assist them to address domestic market challenges by aggressively seeking IAPD, which ultimately leads to regional expansion (Irfan et al., 2019). Therefore, our study contributes by testing theory specifically for Pakistani SMEs and provides important insights into their regional expansion, as they are usually considered inferior due to their weak traditional competitive advantage compared with SMEs from advanced economies.

\section{Theory and Hypotheses Development}

Environmental uncertainty is one of the many facets of the organizational environment that can influence IAPD and the regional expansion of SMEs (Teece et al., 2016). Environmental uncertainty "refers to the extent of unpredictability of conditions in the organization's environment" such as technology, market, institutions, and competition (Peng et al., 2020, p. 115). As environmental uncertainty increases in the domestic markets, it creates pressure for small resource-constrained firms which require inter-functional expertise to remain competitive (Adomako et al., 2019; Packard et al., 2017). In such a situation, an SME's ability to use international strategic alliances and international alliance-based resources plays a vital role in overcoming resource constraints and offering new business opportunities (Torkkeli et al., 2019). International strategic alliances allow an SME to expand the market for its products and services and accumulate resources that are not available in its domestic markets (Ardito et al., 2019; Kwok et al., 2019). From the perspective of the relational view, international strategic alliances are viewed as a source of relational rents and competitive advantage (Robson et al., 2019). In other words, firms that engage in international strategic alliances are expected to reap greater benefits from those relationships because of mutual cooperation and greater knowledge-sharing routines (Dyer et al., 2018).

Researchers studying strategic alliances have argued that strategic objectives such as innovativeness and regional expansion are not achieved through one specific alliance, but through diverse alliance portfolios (Hagedoorn et al., 2018; Subramanian \& Soh, 2017), as firms can obtain complementary and very fine-grained knowledge from diverse partners. Research on alliance partner diversity suggests that cultivation of ties with heterogeneous partners can lead to superior performance because different firms can provide access to diverse knowledge and information (de Leeuw et al., 2014; Robson et al., 2019). Furthermore, alliance partner diversity can provide benefits to SMEs through supporting resource endowments, and economies of scale and scope (Hagedoorn et al., 2018). Of interest to this study, IAPD is likely to influence regional expansion of SMEs. Indeed, IAPD can increase regional expansion by providing an SME with scientific knowledge, hidden international market needs, knowledge about novel products and services, and local contacts in the host markets (Martinez et al., 2017). This is consistent with the relational view, which argues that 


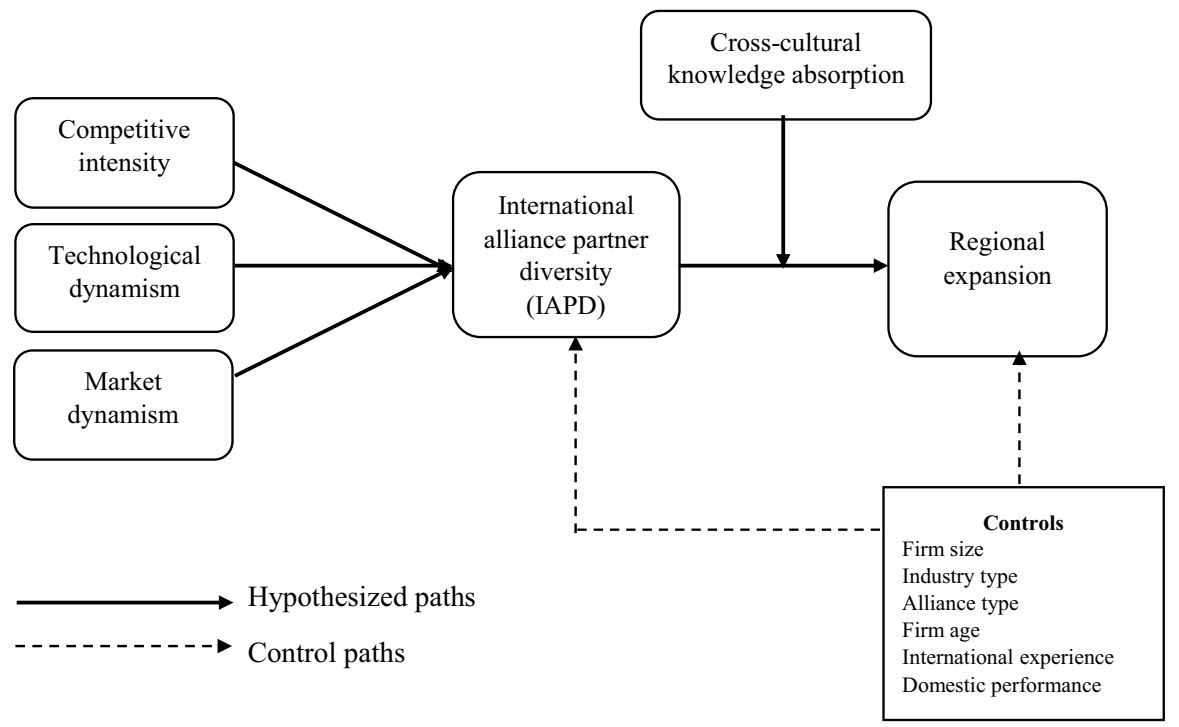

Fig. 1 Conceptual model

increased regional expansion can be achieved by combining the resources of diverse international partners and exploiting possible synergies (Dyer et al., 2018).

Although IAPD is beneficial for regional expansion, the heterogeneous alliance with international partners is a challenging activity due to uncertainty surrounding the management of new operations (Casillas \& Moreno-Menéndez, 2014), as well as not invented here syndrome (Popa et al., 2017), which can hinder the absorption and utilization of diverse knowledge from alliance partners. Such challenges and uncertainties are even more pronounced in contexts-such as those within the Asia-Pacific region - that are characterized by low institutional quality and political instability (Shah et al., 2016). In this regard, the dynamic capability view suggests that SMEs need to possess competencies to develop, alter, and deploy resources in the dynamic market environments (Teece, 2007). Particularly, SMEs require crosscultural knowledge absorption — as a dynamic capability—to identify and integrate knowledge of international partners into regional expansion strategies (Khan \& Lew, 2018). Thus, cultural knowledge absorption can allow an SME to efficiently exchange the knowledge with international partners and maximize the benefits of alliance with diverse partners (Vlaisavljevic et al., 2016). In effect, we contend that the peculiar characteristics of the Asia-Pacific markets (e.g., Pakistan) and of SMEs that operate within these markets means that cross-cultural knowledge acquisition and absorption from international partners is very significant, especially in such challenging and institutionally precarious environments (Nyamrunda \& Freeman, 2021; Osei et al., 2019; Sun et al., 2021).

Building on the relational view (Dyer et al., 2018) and dynamic capability view (Teece, 2007), Fig. 1 shows the study's conceptual framework. The framework indicates that environmental uncertainty leads to IAPD, while IAPD, on the other hand, 
drives regional expansion of SMEs. It further proposes that the relationship between IAPD and regional expansion is contingent on the levels of cross-cultural knowledge absorption.

\section{Domestic environmental uncertainty and international alliance partner diversity}

The relational view posits that resources and value-creation activities span organizational boundaries and are embedded in external relationships (Dyer et al., 2018). The context of the external relationship has implications for the creation and transfer of knowledge. Grounded in trust, these relationships can enable small firms to acquire new knowledge (Lin \& Lin, 2016). Also, by combining resources of the distinct partners, a firm can enjoy synergies that are unavailable to individual alliance partners (Lavie, 2007). Previous literature has also linked alliance diversity and domestic environmental uncertainty. For instance, Marhold and Kang (2017) showed how diversified alliance partners help firms to cope with domestic environmental uncertainty. Similarly, Subramanian and Soh (2017) argued that diverse alliance portfolios allow a firm to manage a high level of environmental uncertainty by creating strategic flexibility. While previous literature has investigated the positive impact of alliance diversity in dealing with the environmental uncertainty, there is a limited understanding of how different dimensions of environmental uncertainty (i.e., market dynamism, technological dynamism, and competitive intensity) will lead to an increase in SMEs' engagement with IAPD.

\section{Competitive intensity and international alliance partner diversity}

Competitive intensity refers to a situation where competition is fierce due to the presence of competitors and the lack of opportunities for growth (Hock-Doepgen et al., 2021). Competitive intensity is related to the competitors' activities, including price competition and promotion wars (Battagila \& Neirotti, 2020). It has been long regarded as a major contributor to environmental uncertainty (Jaworski \& Kohli, 1993). Researchers have contended that, under a situation of high competition, a firm may suffer significant deterioration in performance as customers are freer to change their suppliers (Feng et al., 2019). In the presence of competitive intensity, SMEs need to find ways to differentiate themselves from competitors and offer superior customer benefits over competing firms (Heirati et al., 2016). Given the vigorous competition in the domestic markets, the ideal choice for SMEs is to operate in large international markets (Zahoor and Al-Tabbaa, 2021). Particularly, the relational view suggests that international strategic alliances have evolutionary potential to support SMEs' ability to overcome domestic competitive intensity (Dyer et al., 2018). International strategic alliances can help SMEs to grasp new knowledge, gain foreign market information, and develop competencies (Torkkeli et al., 2019). Under such a condition where uncertainty increases and predictability diminishes, SMEs have a greater need to form alliances to acquire information, lower risks, and reduce competitive intensity (Zahoor et al., 2021). Thus, we extend reasoning from matured economies and assert that developing and emerging economies' SMEs-especially 
those in the Asia-Pacific region-will normally perceive intense competition as a threat and will tend to adopt IAPD (Torkkeli et al., 2019). When competition is intense, SMEs are required to nurture the knowledge capabilities and identify opportunities more rapidly. As such, diverse international partners are likely to provide more information and opportunities for solving problems and reducing uncertainties (Subramanian \& Soh, 2017). Taken together, we predict in our first hypothesis that:

Hypothesis 1: Competitive intensity is positively related to the formation of international alliance partner diversity by the SMEs.

\section{Technological dynamism and international alliance partner diversity}

Technological dynamism is defined as the frequent and volatile changes of technologies, know-how, and innovation (Drnevich \& West, 2021). The causes can originate from the emergence of new technologies and the development of considerable new knowledge. In a dynamic technological environment, the technology of small firms can become obsolete faster and require new technologies to be developed (Popa et al., 2017). As highlighted by Santoro and McGill (2005), the prevalence of technological dynamism suggests that even leading companies cannot develop all the necessary capabilities related to research and development (R\&D) on their own. Prior studies, however, suggest that mature domestic markets together with increased competition encourage SMEs to turn their attention to foreign markets (Torkkeli et al., 2019). By forming international strategic alliances, a resource-constrained SME can complement its internal research and development efforts with complementary resources and knowledge of its international partners (Pervan et al., 2015), thereby providing an avenue to overcome domestic technological dynamism. International alliance partners provide SMEs with access to novel knowledge and offer joint production opportunities in order to maintain competitive advantage (Tower et al., 2021). Some empirical studies in strategic alliance literature lend support to this claim. For example, Brem and Nylund (2021) identified technological dynamism as a critical factor that affects the creation of alliances, and the findings of Musteen et al., (2014b) and Torkkeli et al. (2019) revealed the role of domestic environmental uncertainty for international network formation. Extending this line of reasoning, we expect that technological dynamism in domestic markets encourages SMEs-particularly those in the Asia-Pacific region of Pakistan-to rely on IAPD (Torkkeli et al., 2019). Due to the rise in technological dynamism, such SMEs require a wider range of knowledge to help identify technology and innovation concepts appropriate to local markets (Huo et al., 2018). Different types of alliance partners possess unique knowledge and information that is necessary to overcome technological dynamism, especially in weak institutional environments such as those observed across many emerging markets, including Pakistan. Based on the preceding discussion, we suggest that:

Hypothesis 2: Technological dynamism is positively related to the formation of international alliance partner diversity by the SMEs. 


\section{Market dynamism and international alliance partner diversity}

Market dynamism refers to the rate of change in the domestic market including customer demand and competitor structure (Donbesuur et al., 2020). The domestic market dynamism demands that firms should quickly adjust to external changes, and exploit opportunities presented in such an uncertain environment (Rahman et al., 2020). Emerging markets' SMEs - particularly those in the Asia-Pacific regionmay be susceptible to rapidly changing markets due to their lack of clout and the precarious nature of the institutional environments within which they operate (Nguyen and Özçaglar-Toulouse, 2021; Khan et al., 2018).

Market dynamism therefore intensifies the complexity of the organizational environment as firms need to collect more customer- and market-specific information to develop competitive strategies (Bai et al., 2021). Although these distinctive strategies are developed, firms are stratified in the same segment due to their adoption of similar strategies (Balietti \& Riedl, 2021; Vadakkepatt et al., 2021). Under such conditions, it is difficult for a small resource-constrained firm to offer novel solutions to customers and sustain competitive advantage (Robson et al., 2019). In this context, international strategic alliance plays a crucial role for offering heterogeneous market information and deploying partners' resources to offer innovative products/services (Hung \& Chou, 2013; Shijaku et al., 2020). International partners allow the SMEs to develop combinations of valuable and distinctive resources which otherwise are not available to them (Robson et al., 2019). The relational view also suggests that SMEs pursue international strategic alliances that can provide them with crucial resources that are vital for competitive positioning, enhancing their ability to efficiently react to market changes (Dyer et al., 2018). Particularly, participation in various international alliances (i.e., IAPD) gives SMEs access to diverse types of information on cutting-edge technologies, product developments, and diverse marketplaces, thus increasing opportunities for success in foreign host markets (Solheim, 2016). Moreover, having diverse international partners allows SMEs to be aware of the regulatory environment of each foreign country. Having this knowledge in hand, emerging market SMEs - particularly those of Pakistani origin — can utilize diverse international partners to overcome legitimacy barriers of mimicking and developing innovations for domestic and foreign markets (Sakhdari et al., 2020). Combining the above arguments, we develop our third hypothesis as:

Hypothesis 3: Market dynamism is positively related to the formation of international alliance partner diversity by the SMEs.

\section{International alliance partner diversity and regional expansion of SMEs}

From the relational view perspective, SMEs network with international partners to complement their regional expansion efforts (Khan \& Lew, 2018; Khan et al., 2020; Nyamrunda \& Freeman, 2021). International strategic alliances allow SMEs to identify international opportunities, acquire foreign market knowledge, access strategic resources, and overcome liabilities of newness and foreignness (Robson et al., 2019; 
Stoian et al., 2018). Furthermore, close relationships with international partners can mitigate the risk perception associated with entry in distant markets by providing SMEs with rich information about foreign market conditions (Acosta et al., 2018).

In this study, we argue that IAPD can lead to regional expansion of emerging market SMEs. Particularly, the specific characteristics and objectives of each type of partner lead us to expect that heterogeneous international partners are conducive to Asia-Pacific SMEs' regional expansion. For example, competitors in international markets give access to industry-specific knowledge and resources (Bouncken et al., 2020). By forming alliances with international competitors, SMEs do not need to incur the cost of establishing their own distribution networks, thereby promoting the regional expansion (Nakos et al., 2014). International customers may provide new insights into buyer needs and emerging demand opportunities beyond existing products and markets (Brunswicker \& Vanhaverbeke, 2015). Thereby, SMEs gain knowledge on how to align their strategy, business structure, and products/services to gain legitimacy in foreign markets, thus promoting regional expansion (Nakos et al., 2014). International suppliers provide access to knowledge about the production process and input characteristics that could reduce the cost of the final product/ service and thus promote regional expansion (Bhatti et al., 2020; Kano et al., 2020; Turkina \& Van Assche, 2018). Universities and research institutions in foreign markets provide SMEs with access to new scientific and technological knowledge and the possibility of conducting research (Hervas-Oliver et al., 2016), thereby promoting regional expansion. International consultants can be valuable sources to provide engineering capabilities and marketing knowledge to commercialize products and services in international markets, thus enhancing regional expansion (Blackburne \& Buckley, 2019; Catanzaro et al., 2019).

Consistent with the foregoing line of reasoning, IAPD enhances the amount and variety of knowledge related to the political, cultural, and legal environments (Torkkeli et al., 2019). This knowledge, in turn, leads to better understanding of international market opportunities and the chance to expand foreign sales base. For example, within emerging economy SMEs, and particularly within the South Asia-Pacific regional context, there may be differences in institutions, trust levels, and cooperation among countries (Bruton \& Lau, 2008) — this may give rise to strengthening of IAP among SMEs that want to remain competitive. Moreover, IAPD can enhance an SME's capabilities for information searching and learning, subsequently augmenting its knowledge base and improving regional expansion. In sum, SMEs with IAPD can benefit from regional expansion due to better appreciation of foreign market opportunities and risks. Based on these arguments, we develop our fourth hypothesis as:

Hypothesis 4: International alliance partner diversity is positively related to regional expansion by SMEs.

\section{The moderating role of cross-cultural knowledge absorption}

International strategic alliance is a challenging activity due to the uncertainty and risk involved in management of new foreign routines (Li \& Reuer, 2021). Indeed, 
international alliances with diverse partners entail more complexity as heterogeneous and complex organizational systems are linked together in specific ways (Kok et al., 2020). SMEs must have and be able to implement the ability to effectively exchange knowledge with their international partners to enhance regional expansion (Nyamrunda \& Freeman, 2021). The dynamic capability view (Teece, 2007; Teece et al., 2016) argues that regional expansion by allying with diverse international partners requires capabilities to facilitate knowledge exchange in dynamic marketplaces. Thus, cross-cultural knowledge absorption is the ability of an SME to effectively integrate and exploit knowledge, "which provides an individual within the organization with a common vision to achieve interaction" (Zhang et al., 2018, p. 629), thereby promoting regional expansion. The relatively heterogeneous cultural characteristics of countries within the Asia-Pacific region mean that cultural adaptability and cross-cultural knowledge absorption will be a significant asset to the internationalization success of SMEs (He et al., 2020). Since IAPD involves different partners, the successful knowledge exchange among them requires that all partners receive the same information and benefit from joint interactions (Nyamrunda \& Freeman, 2021). While differences in culture within the Asia-Pacific region may present some ambiguity and interference in knowledge exchanges (Ferraris et al., 2019; Wang \& Chung, 2020), the essence of cross-cultural knowledge absorption in part requires SMEs to be able to navigate and integrate perceived cultural and institutional differences within the regional block. Therefore, by utilizing cross-cultural knowledge absorption, SMEs can narrow the cultural differences with their partners and effectively share and combine their knowledge with that of their partners (Ferreras-Mendez et al., 2019). In this regard, when SMEs have the cross-cultural knowledge absorption capability, it is easier for them to benefit from diverse alliance partners and thus achieve regional expansion (Hennart et al., 2019). In the same vein, at lower levels of cross-cultural knowledge absorption capability, SMEs will not be able to fully utilize the information from their IAPD portfolio about the target foreign regional market, in turn, weakening regional expansion (Wang \& Chin, 2020).

Accordingly, we posit that, the more SMEs of Asia-Pacific origin possess crosscultural knowledge absorption capability, the easier it will be for them to obtain and utilize the resources and knowledge from their international diverse partners portfolio, strengthening regional expansion. Consequently, we posit that cross-cultural knowledge absorption strengthens the relationship between IAPD and regional expansion.

Hypothesis 5: The positive relationship between international alliance partner diversity and SMEs' regional expansion is positively moderated by cross-cultural knowledge absorption.

\section{Methodology}

\section{Study context}

The study hypotheses were tested on a sample of SMEs in Pakistan. Our samples consist of SMEs exporting industrial products from Pakistan to other Asia-Pacific 
countries. In Pakistan, SMEs account for approximately $90 \%$ of all enterprises, employ $80 \%$ of the non-agricultural workforce, and contribute nearly $40 \%$ to the annual GDP (Trading Economics, 2020). Despite the dominant nature of SMEs within the business environment, Pakistan is a relatively less-studied country in comparison to other similar countries in the BRICS region. Pakistan is a fast-growing economy-with the annual GDP growth rate increasing from 3.84\% in 2012 to 5.79\% in 2018 (Trading Economics, 2020). The infrastructure of Pakistan has been evolving over the years, and is now positioning toward further growth. The country has exporting and investment advantages due to its strategic location and proximity to China, India, and other emerging Asian economies. More specifically, Pakistan exported \$26.8B in 2018, where most of the exports were to China (\$1.95B) and Afghanistan (\$1.78B). Despite being an active exporter, Pakistan has constantly experienced domestic turbulence-mainly due to tensions with neighboring countries like India (Khan \& Lew, 2018). Pakistan has been subjected to a volatile political situation, continuously altering between a military and a democratic government (Shah et al., 2016). The country also suffers from high levels of corruption, ineffective governance, and weak enforcement of laws (Uddin et al., 2019). With this mixture of growth potential within exporting SMEs and environmental turbulence on the other hand, Pakistan provides a useful context within which we can expand our understanding of the phenomenon of SMEs' regional expansion.

\section{Sampling and data collection}

The targeted population of this study is Pakistani SMEs that are active exporters to the Asia-Pacific region. The study sample was obtained from the Pakistan Export Directory, Pakistan Chamber of Commerce and Industry Directory, and the Small and Medium Enterprises Development Authority (SMEDA) databases. To be eligible to participate in the study, firms must meet the following conditions: (1) be operating in the manufacturing, services, and retail industries; (2) be independent entities and not operating under any group; (3) employ fewer than 250 employees; (4) be exporting to other areas in the Asia-Pacific region ${ }^{2}$; and (5) have complete contact information on the chief executive officer (CEO) and senior managers. In total, we identified 630 firms as those that meet our study criteria. Accordingly, we contacted these firms by telephone to confirm their participation in our study. In all, $356(56.50 \%)$ agreed to participate in the study-to which 356 questionnaires were sent accordingly.

In March 2019, the survey was administered using the hand-delivery approach with the help of research assistants (e.g., Boso et al., 2018). Extensive training was provided to all research assistants to ensure that they had the competency to explain relevant portions of the questionnaire to respondents if and when necessary. As part

\footnotetext{
${ }^{2}$ Given the study's focus and consistent with previous exporting literature (e.g., Boso et al., 2019; Love et al., 2016; Oura et al., 2016), we focused only on SMEs that are already involved in export activities. This helped us to understand how domestic market environmental uncertainty promotes IAPD and subsequently regional expansion of SMEs.
} 
of ensuring the reliability of the responses, participants were asked to rate their: (1) knowledge on the subject(s) under investigation; and (2) confidence in the answers to the questions (Boso et al., 2013). We sent two reminders to the respondents and consequently received 232 complete responses, yielding a response rate of $65.17 \%$. The results revealed a mean score of 6.56 for knowledge on subject and 6.76 for confidence in the answers.

To assess non-response bias, we compared two groups: early responses and late responses (Armstrong \& Overton, 1977). The results of a t-test revealed no significant difference between the two groups in relation to demographic variables (e.g., firm size, firm age, and international experience) and focal study variables (e.g., market dynamism and regional expansion), suggesting non-response bias is not an issue in this study. The participating firms had operations in the manufacturing $(40.5 \%)$, services $(30.6 \%)$, and retail $(28.9 \%)$ industries. The firms had been in operation for an average of 14 years. The average number of full-time employees was 89 . On average, the firms had been conducting international operations for five years.

\section{Measures}

The study measures were adapted from existing studies within the extant literature. Details of all measurement items are explained and summarized in Table 1.

Environmental uncertainty is defined as the extent of market dynamism, technological dynamism, and competitive intensity (Jaworski \& Kohli, 1993). Adopting from Grewal and Tansuhaj (2001) and Jaworski and Kohli (1993), market dynamism was measured using five items, technological dynamism was measured using four items, and competitive intensity was measured using four items. Each item was measured on a seven-point Likert scale $(1=$ strongly disagree, and $7=$ strongly agree).

$I A P D$ is defined as the diversity of an SME's international alliance partners. To construct this variable, the respondent firms were asked if they formed an alliance with partners within the Asia-Pacific region. The partners were distinguished into seven types: customers, suppliers, competitors, commercial laboratories, research institutes, universities, and others. Based on this question, and following de Leeuw et al. (2014) and Oerlemans et al. (2013), we created an IAPD variable by dividing the number of different types of partners maintained by the firm by the maximum possible number of different partners (in our case seven) and squaring the result of this division. It is important to note that this measure indicates IAPD and not alliance portfolio size.

Cross-cultural knowledge absorption concerns the ability of a firm to transfer, assimilate, and apply the knowledge of international partners (Zhang et al., 2018). It was operationalized using four items adapted from Su et al. (2013) and Zhang et al. (2018). The items were scored using the seven-point Likert scale $(1=$ strongly disagree, and $7=$ strongly agree).

Regional expansion is operationalized as the extent of an SME's international activities and operations beyond the boundaries of its domestic markets (Boso et al., 2017; Hitt et al., 1994). Specifically, we focus on SMEs' international expansion 


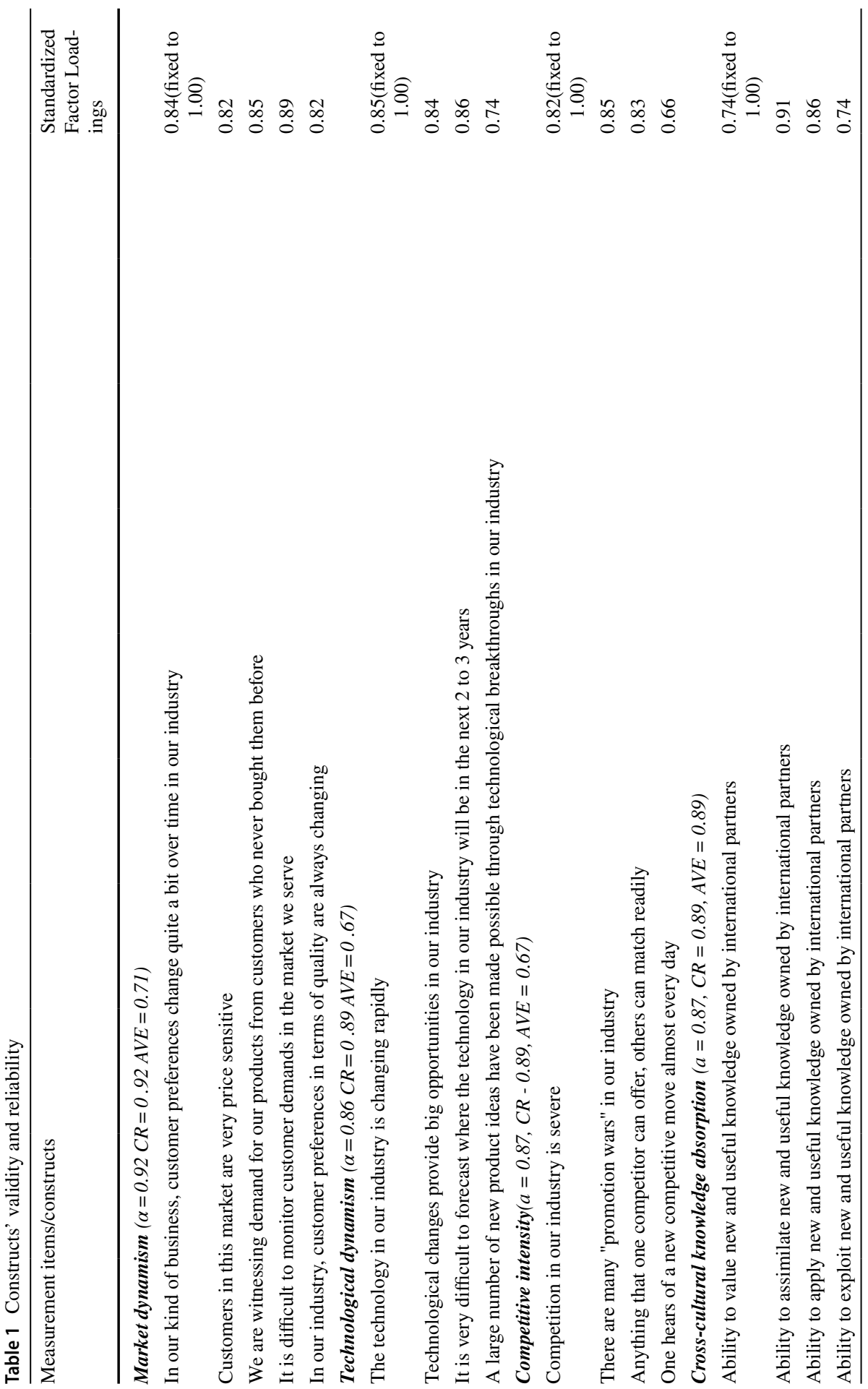




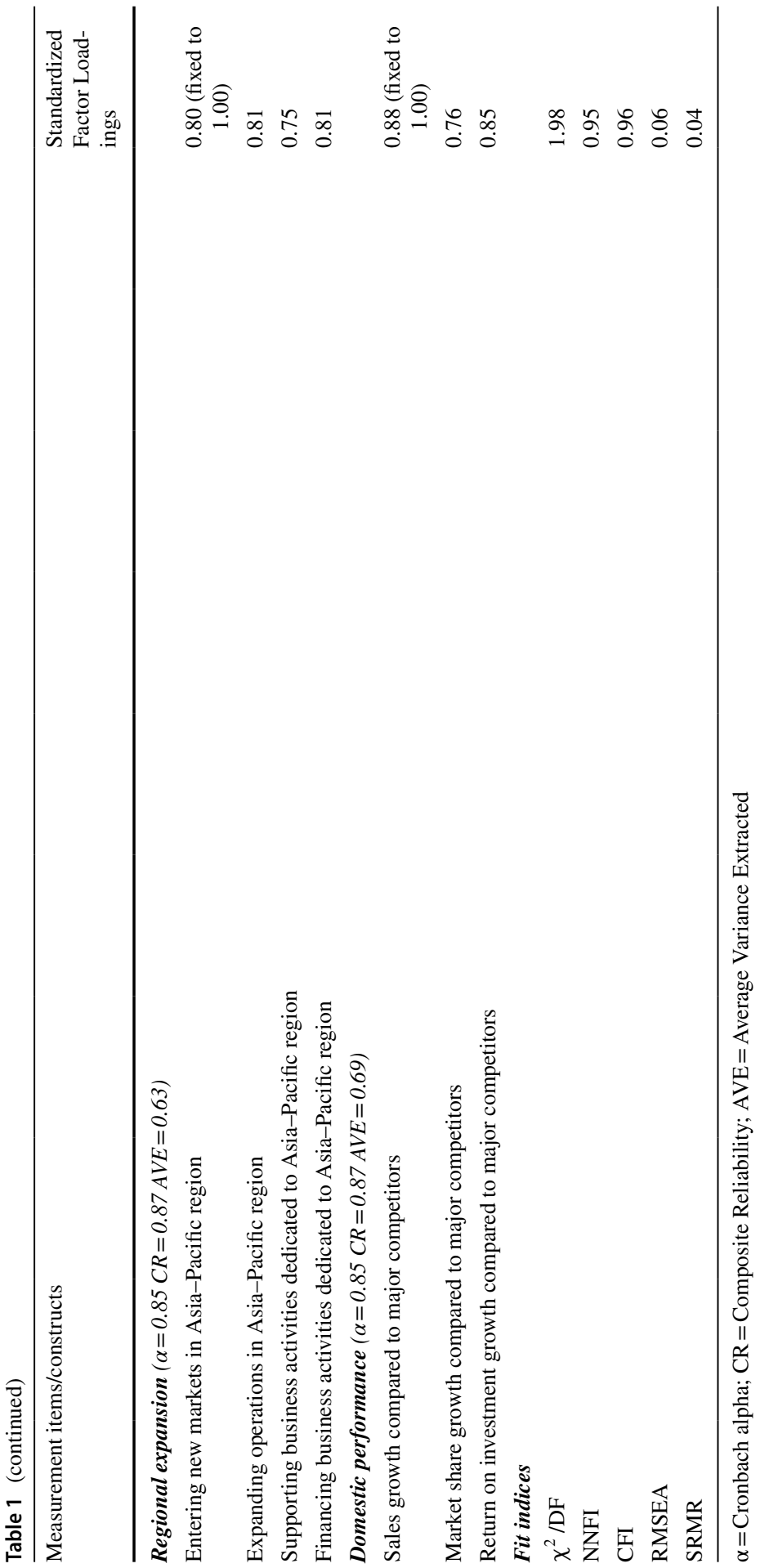


within the Asia-Pacific markets (Zahra, 2020). It was measured using four items developed by Zahra et al. (2000), and widely used in international business literature (e.g., Adomako et al., 2020; Yiu et al., 2007). The respondents were asked to evaluate the extent of regional expansion in the past three years along a seven-point Likert scale $(1=$ very small extent, and $7=$ very large extent $)$.

Control variables: We included a number of control variables in our model: The literature suggests that firm size impacts on regional expansion of SMEs (Dooley et al., 2016). As size increases, firms may enjoy competitive advantage in terms of resource availability, and economies of scale, which may enhance their chances of regional expansion. Accordingly, we included firm size (measured as the logarithm of the number of employees) as a control variable. Firm age (as the number of years between the establishment of the firm and the observation year) was also a control variable in our study as it can influence alliance practices and regional expansion (Nakos et al., 2019). Industry was also included as a control variable because SMEs operating in different industrial sectors have different propensities to export (Garcia Martinez et al., 2017). Thus, we created three industry dummy variables identifying manufacturing, services, and retail. In addition, alliance experience (measured as the number of alliances a firm formed during the last three years) was included because a higher level of alliance participation increases the likelihood of knowledge acquisition for regional expansion. International experience of a firm can also influence the regional expansion of an SME due to learning from previous international operations. It was included as a control variable and measured as the number of years a firm had been operating internationally (Casillas \& Moreno-Menéndez, 2014). Finally, the domestic performance was added as a control variable because the success of a firm in domestic markets can influence the alliance partner diversity and regional expansion. It was measured using three items adapted from Lii and Kuo (2016).

\section{Analyses}

\section{Reliability and validity assessment}

We conducted confirmatory factor analysis (CFA) to establish the reliability and validity of the multi-item measures. Following previous recommendations (e.g., Bagozzi \& Yi, 2012; Kline, 2015), we assessed the fitness of our model using: (1) absolute fit indices such as Standardized Root Mean Squared Residual (SRMR), (2) non-centrality-based measures such as Root Mean Square Error of Approximation (RMSEA), and (3) relative fit indices including Non-Normed Fit Index (NNFI) and Comparative Fit Index (CFI). Thus, the CFA provided the following model fit indices for the data: $\chi 2 /$ d.f. $=1.98$; NNFI $=0.95 ; \mathrm{CFI}=0.96 ; \mathrm{RMSEA}=0.06$; and $\mathrm{SRMR}=0.04-$ all of which fall within the acceptable range of values. Further, all measurement items loaded significantly onto their respective constructs, with the standardized factor loadings for each item being significant at $1 \%$. Again, to ensure internal consistency and convergent validity of our measurement items, the Cronbach's alpha and the composite reliability (CR) values for all factors exceeded the 
acceptable benchmarks of 0.70 and 0.60 respectively (Fornell \& Larcker, 1981). Lastly, we establish discriminant validity by comparing the average variance extracted (AVE) for each construct and the highest shared variance (HSV) of each pair of constructs. The results indicate that each of the AVEs is greater than the shared variance of any pair of constructs. Table 1 provides the detailed result of our model fit estimation and description of all measurement items, while Table 2 shows the descriptive statistics and correlation coefficients among the constructs.

\section{Common method bias assessment}

We followed two recommended steps to ensure that common method bias does not sufficiently describe our data. First, we used ex-ante procedures (e.g., Podsakoff et al., 2003) by obtaining data on the dependent and independent variables from different sources. Second, as an ex-post procedure, we performed one statistical analysis during the data analysis stage to check the presence of common method bias in the data. Following recommended practices, we estimated three competing CFAs (model 1, model 2, and model 3) to test for common method bias (e.g., Chang et al., 2010). Model 1 is an estimation of a method-only model in which all items are loaded on a single latent factor, with the following fit indices: $\chi^{2 / \text { d.f. }}=11.67$; $\mathrm{NNFI}=0.69 ; \mathrm{CFI}=0.71 ; \mathrm{RMSEA}=0.22$; and $\mathrm{SRMR}=0.14$. In Model 2, we estimated a trait-only model where each item is loaded on its theoretical factor. The fit indices for Model 2 include: $\chi 2 /$ d.f. $=1.98 ; \mathrm{NNFI}=0.95 ; \mathrm{CFI}=0.96$; $\mathrm{RMSEA}=0.06$; and $\mathrm{SRMR}=0.04$. The third model is a method-and trait-model which estimates both Model 1 and Model 2 in a single framework. Model 3 provides the following fit statistics: $\chi 2 /$ d.f. $=1.84 ; \mathrm{NNFI}=0.97 ; \mathrm{CFI}=0.98 ; \mathrm{RMSEA}=0.05$; and SRMR $=0.04$. A look at the three competing CFAs shows that Model 2 and Model 3 are better than Model 1 on the one hand, and models 2 and 3 are almost identical. With this, we can assume that common method bias does not impact on our study results.

\section{Model estimation}

We employ main effects and moderated hierarchical regression analysis to test the hypothesized relationships. To create the interaction term (IAPD x cross-cultural knowledge absorption), we mean-centered the variables, so as to reduce the occurrence of multicollinearity in our regression estimates. In all, five models were estimated. Model 1 and Model 2 have IAPD as the dependent variable. In Model 1, we estimate the effects of the control variables, while Model 2 estimates the effects of technological dynamism, market dynamism, and competitive intensity on IAPD. Models 3, 4, and 5 have regional expansion as an outcome variable. In Model 3, we regress the study's control variables on regional expansion, while Model 4 shows the direct effect of IAPD on regional expansion. Finally, we estimate a 5 th model that contains the effect of the interaction term (IAPD x cross-cultural knowledge absorption). Table 3 shows the regression estimates and associated fit statistics of our hypothesized relationships. 


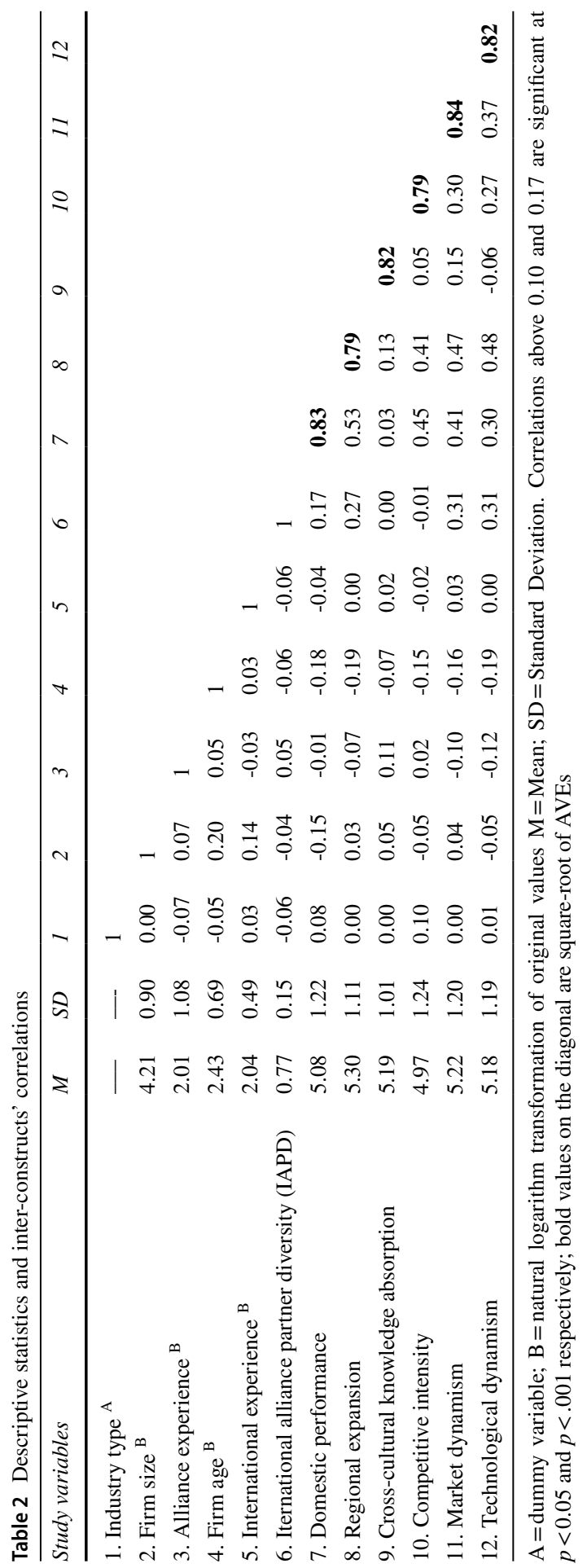




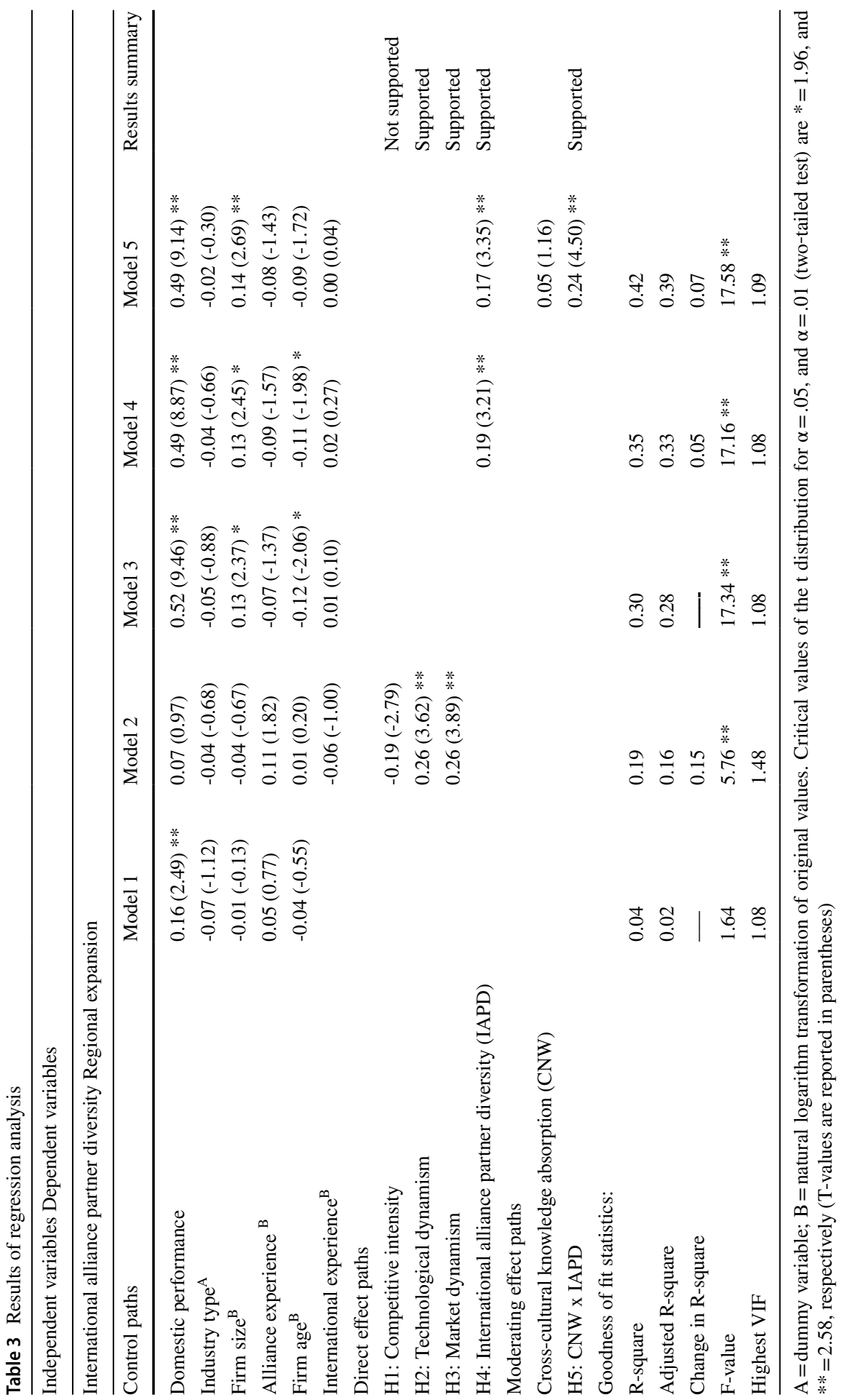




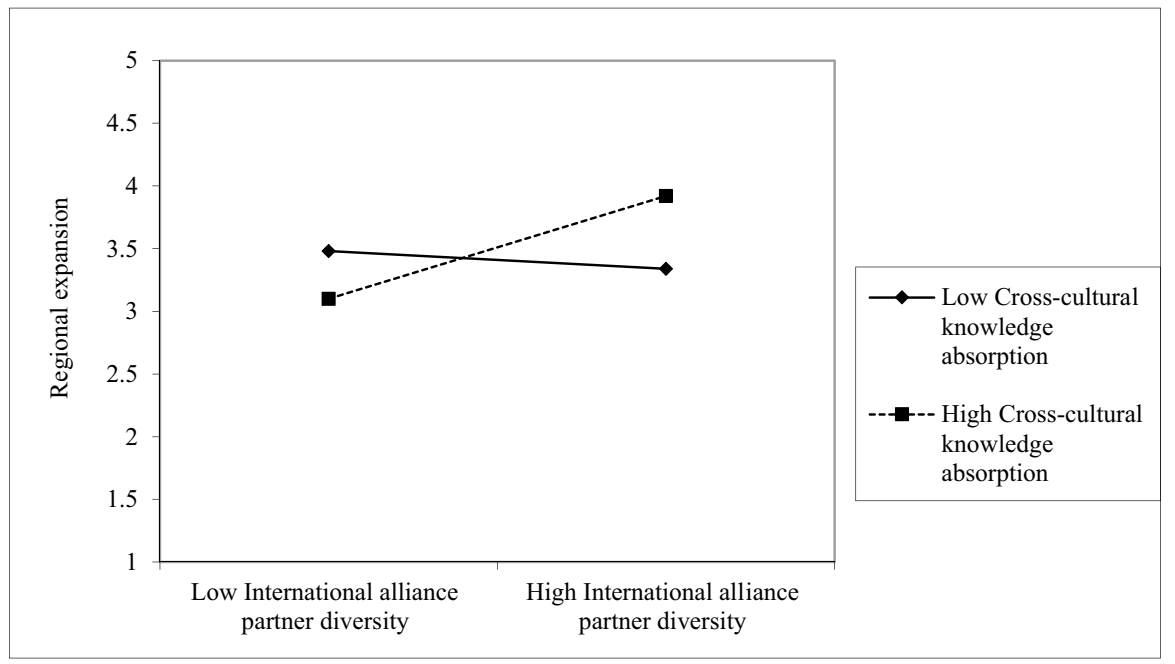

Fig. 2 The moderating effect of cross-cultural knowledge absorption on the relationship between international alliance partner diversity and regional expansion

\section{Findings}

The study proposed five hypotheses. H1 - H3 argue for a relationship between three domestic environmental uncertainty variables (competitive intensity, technological dynamism, and market dynamism) and IAPD, while H4 and H5 posit a relationship between IAPD and SMEs' regional expansion and the moderating effect of crosscultural knowledge absorption on the IAPD-regional expansion relationship, respectively. Specifically, we hypothesized that competitive intensity $(\mathrm{H} 1)$, technological dynamism (H2), and market dynamism (H3) have a positive relationship with IAPD. From our regression analysis, we find support for both $\mathrm{H} 2$ and $\mathrm{H} 3$ that technological dynamism $(\beta=0.26 ; \mathrm{t}=3.62 ; \mathrm{p}<0.01)$ as well as market dynamism $(\beta=0.26$; $\mathrm{t}=3.89 ; \mathrm{p}<0.01$ ) have a positive effect on SMEs' IAPD. Contrary to our argument for $\mathrm{H} 1$, we find no support that competitive intensity positively drives IAPD of manufacturing SMEs $(\beta=-0.19 ; \mathrm{t}=-2.79 ; \mathrm{p}<0.01)$.

The second part of our model makes arguments for a positive relationship between IAPD and regional expansion $(\mathrm{H} 4)$ and a positive moderating effect of cross-cultural knowledge absorption on the relationship between IAPD and regional expansion (H5), on the other hand. Accordingly, we find support for H4 that IAPD positively drives regional expansion of SMEs $(\beta=0.19 ; \mathrm{t}=3.21 ; \mathrm{p}<0.01)$. Further, the moderating effect analysis shows that the positive relationship between IAPD and regional expansion is strengthened by cross-cultural knowledge absorption $(\beta=0.24 ; \mathrm{t}=4.50 ; \mathrm{p}<0.01)$, supporting H5. To enhance our understanding of the significance of the interaction effect, we followed recommendations by Dawson and Richter (2006) to plot a two-way interaction graph that shows the effect of IAPD on regional expansion for values of cross-cultural knowledge absorption. Figure 2 indicates that there is a positive moderating effect of cross-cultural knowledge 
absorption on the relationship between IAPD and regional expansion. Specifically, high levels of both IAPD and cross-cultural knowledge absorption enhance the regional expansion of SMEs.

\section{Discussion and implications}

Building on the relational and dynamic capability views, our study examines if the different dimensions of domestic market environmental uncertainty propel SMEs to engage with their IAPD portfolio and how the effects of IAPD for regional expansion differ under different conditions of cross-cultural knowledge absorption. In this vein, we tested our hypotheses on a sample of 232 SMEs operating in Pakistan. Findings from our study show that: (1) not all dimensions of domestic market environmental uncertainty drive SMEs to engage with their IAPD portfolio, i.e., technological and market dynamism are positively associated with IAPD while domestic market competitive intensity is not; (2) IAPD is positively associated with SMEs' regional expansion; and (3) cross-cultural knowledge absorption positively moderates the relationship between IAPD and regional expansion, i.e., at higher levels of cross-cultural knowledge absorption, the relationship between IAPD and SMEs' regional expansion is strengthened. These findings have significant implications for SMEs (and particularly, Asia-Pacific SMEs) that engage in internationalization and regional expansion activities, and the international entrepreneurship literature.

\section{Theoretical implications}

Our findings make several contributions to the extant literature by drawing empirical insights from Pakistani SMEs. First, building on the relational view, we find that not all three dimensions of domestic market environmental uncertainty drive SMEs to engage with their IAPD portfolio. Specifically, our findings show that domestic market competitive intensity is not positively associated with IAPD. This finding suggests that, in the presence of intense domestic market competition, emerging market SMEs (such as those within the Asia-Pacific region) initially focus on outperforming their domestic competitors-through providing superior goods and services to their customers - rather than utilizing their IAPD portfolio (Heirati et al., 2016). This entails that, under intense domestic market competition, SMEs focus on their survival - due to their resource deficiencies and lack of capabilities-rather than engaging with their IAPD portfolios (Iurkov \& Benito, 2018). Thus, emerging market SMEs must overcome the market competitive intensity in their domestic markets before utilizing their IAPD. Furthermore, our findings reveal that domestic market technological and market dynamism propel emerging market SMEs to engage with their IAPD portfolio (Drnevich \& West, 2021). Due to the unpredictability in their domestic markets, emerging market SEMs-especially those in the Asia-Pacific region-rely on their IAPD to gain novel knowledge to help identify technology, innovation concepts, and customer information appropriate to target foreign markets (Hao et al., 2020; Huo et al., 2018; Robson et al., 2019). In sum, 
our findings contribute to the relational view theory by presenting the differential domestic market environment levels under which emerging market SMEs utilize their IAPD portfolios.

Second, we found quantitative evidence that there is a positive relationship between IAPD and SME regional expansion. Again, building on the relational view, this finding points that SMEs tap into their IAPD portfolio to complement their efforts for regional expansion (Robson et al., 2019). In this vein, international partners enable SMEs to identify opportunities across target regional markets, acquire foreign market knowledge, access strategic resources, and overcome liabilities of newness and foreignness, which are of crucial importance in their regional expansion (Stoian et al., 2018). Importantly, our findings show that these relationships with their international partners help Pakistani SMEs to mitigate the risks associated with entering a new regional market while providing knowledge on how Pakistani SMEs align their strategy, business structure, and products/services to gain legitimacy in their target foreign regional markets, in turn, strengthening regional expansion (Nakos et al., 2014). Thus, extending the relational view, we find that IAPD portfolios provide market, political, cultural, and legal knowledge to resource-constrained Pakistani SMEs (Sinkovics et al., 2019; Stoian et al., 2018). In turn, this knowledge provides market opportunities in the target foreign market, which is paramount for the regional expansion of Pakistani SMEs.

Third, we find that, at higher levels of cross-cultural knowledge absorption, the positive effect of IAPD on regional expansion is strengthened. In line with the dynamic capability view, our findings show that, when SMEs adopt cross-cultural knowledge absorption capabilities that enable them to facilitate knowledge exchange about their regional target market, the effect of IAPD on regional expansion is higher (Ferreras-Mendez et al., 2019; Hennart et al., 2019; Nyamrunda \& Freeman, 2021). Hence, our findings show that, by utilizing higher levels of cross-cultural knowledge absorption, Pakistani SMEs can narrow the cultural differences in their target regional market and with their partners-enabling them to effectively share and combine their knowledge with that of their partners, to strengthen regional expansion (Ferraris et al., 2019; Osei et al., 2019; Wang \& Chin, 2020). In this regard, at higher levels of cross-cultural knowledge absorption capability, Pakistani SMEs are better placed to utilize the information and knowledge from their IAPD, in turn, strengthening regional expansion.

Finally, we contribute to dynamic capability theory and IAPD literature by testing our theoretical framework on a unique and rarely studied sample of Pakistani SMEs. SMEs account for approximately $90 \%$ of all enterprises in Pakistan, employ $80 \%$ of the non-agricultural workforce, and contribute nearly $40 \%$ to the annual GDP. However, Pakistani SMEs face fierce domestic market environmental uncertainty due to a weak institutional system and lack of property rights protection regimes. Under these conditions, Pakistani SMEs nurture strategic agility as their dynamic capability that allows them to overcome domestic market environmental uncertainty and establish a presence across other regional markets (Khan, 2020; Shams et al., 2021). As such, our study contributes to the dynamic capability literature by providing insights into the regional expansion of SMEs in an uncertain environment. Specifically, within the dynamic and uncertain nature of the Pakistani domestic market, 
SMEs can draw on their dynamic capability (i.e., strategic agility) to swiftly identify domestic market trends and engage in IAPD portfolios (Osei et al., 2019; Robson et al., 2019). By actively participating in an IAPD portfolio, Pakistani SMEs can overcome domestic market environmental uncertainty as well as obtain vital information and knowledge for regional expansion (Robson et al., 2019). More importantly, cross-cultural knowledge absorption is a necessary dynamic capability for Pakistani SMEs to effectively obtain and accumulate knowledge from diverse international partners to attain regional expansion (Nyamrunda \& Freeman, 2021).

\section{Practical implications}

Our study has several practical implications. First, managers of Pakistani SMEs can leverage the domestic market environmental uncertainty to utilize IAPD portfolios in order to achieve regional expansion. Specifically, the results of our study suggest that dimensions of domestic market environmental uncertainty are effective drivers of IAPD which ultimately lead to regional expansion of Pakistani SMEs, as such firms use it as an escape strategy to venture into regional markets. Therefore, SME managers operating in these contexts are advised to leverage domestic market environmental uncertainty for regional expansion by developing their strategic agility and establishing IAPD portfolios. Second, we find that IAPD has different impacts on regional expansion of Pakistani SMEs depending on their cross-cultural knowledge absorption. Pakistani SME managers should be advised that IAPD may not lead to regional expansion if they have low cross-cultural knowledge absorption. Therefore, Pakistani SMEs must invest in the development of cross-cultural knowledge absorption because it can facilitate greater regional expansion from IAPD. These firms can offer training programs, regional trade fairs, and international networking opportunities for the exchange of knowledge, which can inform their crosscultural knowledge absorption capability. Accordingly, Pakistani SMEs can survive in volatile contexts by capitalizing on their IAPD portfolios for knowledge and innovation that can influence regional expansion.

\section{Limitations and further research avenues}

Like with most research studies, there are limitations associated with these current findings, which provide an avenue for future research directions. First, it is important for future studies to examine which aspects and types of IAPD are most important for SME regional expansion. For instance, our current study fails to specify which IAPD portfolio would be most important for SMEs' regional expansion. Thus, further studies could examine the reasoning underlying different IAPD types depending on the nature, structure, and ties to the alliances. Second, there are other environmental-related variables (e.g., enhanced institutional support system in domestic markets) and firm-level contingent variables (e.g., financial resource) that will drive SMEs to engage in IAPD portfolios for regional expansion. A meaningful extension of this study might examine other external and firm-related variables that lead to increases in IAPD in SMEs and other performance-related consequences of IAPD 
in the SME domain. Third, our study focused on IAPD, thereby disregarding the domestic alliance partner diversity (DAPD). Due to this, we were not able to disentangle the differential impact of industry and firm size on building IAPD vs. DAPD. Therefore, future studies could consider both IAPD and DPAD and determine their varying effects on the regional expansion of SMEs.

\section{Conclusion}

What aspects of environmental uncertainty and firm-level capabilities drive SMEs' regional expansion? Our findings, based on a sample of 232 Pakistani SMEs, show that technological and market dynamism drive SMEs to draw on their IAPD while competitive intensity has no positive effect. Instead, when competition intensity is high, SMEs focus on providing superior goods and services to outperform their competitors rather than drawing attention to their IAPD portfolio. In the same vein, engaging in IAPD portfolios aids SMEs to expand into regional markets and even more so at high levels of cross-cultural knowledge absorption. We conclude by positing that SMEs' regional expansion depends partially on factors existent in the domestic market environment and international relational characteristics. Thus, this study sets the stage for further empirical research relating to the role of domestic market environmental uncertainties and IAPD in the regional expansion processes of SMEs that may involve other internal and external variables in different research settings.

Open Access This article is licensed under a Creative Commons Attribution 4.0 International License, which permits use, sharing, adaptation, distribution and reproduction in any medium or format, as long as you give appropriate credit to the original author(s) and the source, provide a link to the Creative Commons licence, and indicate if changes were made. The images or other third party material in this article are included in the article's Creative Commons licence, unless indicated otherwise in a credit line to the material. If material is not included in the article's Creative Commons licence and your intended use is not permitted by statutory regulation or exceeds the permitted use, you will need to obtain permission directly from the copyright holder. To view a copy of this licence, visit http://creativecommons.org/licen ses/by/4.0/.

\section{References}

Acosta, A. S., Crespo, Á. H., \& Agudo, J. C. (2018). Effect of market orientation, network capability and entrepreneurial orientation on international performance of small and medium enterprises (SMEs). International Business Review, 27(6), 1128-1140.

Adomako, S., Amankwah-Amoah, J., Dankwah, G. O., Danso, A., \& Donbesuur, F. (2019). Institutional voids, international learning effort and internationalization of emerging market new ventures. Journal of International Management, 25(4), 100666.

Adomako, S., Frimpong, K., Danso, A., Amankwah-Amoah, J., Uddin, M., \& Kesse, K. (2020). Home country institutional impediments and international expansion of developing country SMEs. International Business Review, 101716. 
Ahammad, M. F., Basu, S., Munjal, S., Clegg, J., \& Shoham, O. B. (2021). Strategic agility, environmental uncertainties and international performance: The perspective of Indian firms. Journal of World Business, 56(4), 101218.

Andersson, S., Evers, N., \& Griot, C. (2013). Local and international networks in small firm internationalization: Cases from the Rhône-Alpes medical technology regional cluster. Entrepreneurship \& Regional Development, 25(9-10), 867-888.

Ardito, L., Peruffo, E., \& Natalicchio, A. (2019). The relationships between the internationalization of alliance portfolio diversity, individual incentives, and innovation ambidexterity: A microfoundational approach. Technological Forecasting and Social Change, 148, 119714.

Armstrong, J. S., \& Overton, T. S. (1977). Estimating nonresponse bias in mail surveys. Journal of Marketing Research, 14(3), 396-402.

Bagozzi, R. P., \& Yi, Y. (2012). Specification, evaluation, and interpretation of structural equation models. Journal of the Academy of Marketing Science, 40(1), 8-34.

Bai, C., Gao, W., \& Sarkis, J. (2021). Operational risks and firm market performance: Evidence from China. Decision Sciences, 52(4), 920-951.

Balietti, S., \& Riedl, C. (2021). Incentives, competition, and inequality in markets for creative production. Research Policy, 50(4), 104212.

Battaglia, D., \& Neirotti, P. (2020). Dealing with the tensions between innovation and internationalization in SMEs: A dynamic capability view. Journal of Small Business Management, 1-41.

Bhatti, W. A., Larimo, J., \& Servais, P. (2020). Relationship learning: A conduit for internationalization. International Business Review, 101694.

Blackburne, G. D., \& Buckley, P. J. (2019). The international business incubator as a foreign market entry mode. Long Range Planning, 52(1), 32-50.

Boso, N., Adeola, O., Danso, A., \& Assadinia, S. (2019). The effect of export marketing capabilities on export performance: Moderating role of dysfunctional competition. Industrial Marketing Management, 78, 137-145.

Boso, N., Annan, J., Adeleye, I., Iheanachor, N., \& Narteh, B. (2018). Examining the paths from export strategic orientations to export performance: The mediating role of export resource transformation capability. Thunderbird International Business Review, 60(2), 207-230.

Boso, N., Oghazi, P., \& Hultman, M. (2017). International entrepreneurial orientation and regional expansion. Entrepreneurship \& Regional Development, 29(1-2), 4-26.

Boso, N., Story, V. M., Cadogan, J. W., Micevski, M., \& Kadić-Maglajlić, S. (2013). Firm innovativeness and export performance: Environmental, networking, and structural contingencies. Journal of International Marketing, 21(4), 62-87.

Bouncken, R. B., Fredrich, V., Ritala, P., \& Kraus, S. (2020). Value-creation-capture-equilibrium in new product development alliances: A matter of coopetition, expert power, and alliance importance. Industrial Marketing Management, 90, 648-662.

Brem, A., \& Nylund, P. A. (2021). Maneuvering the bumps in the New Silk Road: Open innovation, technological complexity, dominant design, and the international impact of Chinese innovation. $R \& D$ Management, 51(3), 293-308.

Brunswicker, S., \& Vanhaverbeke, W. (2015). Open innovation in small and medium-sized enterprises (SMEs): External knowledge sourcing strategies and internal organizational facilitators. Journal of Small Business Management, 53(4), 1241-1263.

Bruton, G. D., \& Lau, C. M. (2008). Asian management research: Status today and future outlook. Journal of Management Studies, 45(3), 636-659.

Buccieri, D., Javalgi, R. G., \& Cavusgil, E. (2020). International new venture performance: Role of international entrepreneurial culture, ambidextrous innovation, and dynamic marketing capabilities. International Business Review, 29(2), 101639.

Casillas, J. C., \& Moreno-Menéndez, A. M. (2014). Speed of the internationalization process: The role of diversity and depth in experiential learning. Journal of International Business Studies, 45(1), 85-101.

Catanzaro, A., Messeghem, K., \& Sammut, S. (2019). Effectiveness of export support programs: Impact on the relational capital and international performance of early internationalizing small businesses. Journal of Small Business Management, 57(sup2), 436-461.

Chan, R. Y., He, H., Chan, H. K., \& Wang, W. Y. (2012). Environmental orientation and corporate performance: The mediation mechanism of green supply chain management and moderating effect of competitive intensity. Industrial Marketing Management, 41(4), 621-630. 
Chang, SJ., van Witteloostuijn, A. \& Eden, L. From the Editors: Common method variance in international business research. Journal of International Business Studies 41, 178-184 (2010). https://doi. org/10.1057/jibs.2009.88

Chetty, S., \& Campbell-Hunt, C. (2003). Paths to internationalisation among small- to medium-sized firms: A global versus regional approach. European Journal of Marketing, 37(5/6), 796-820.

Child, J. (1972). Organizational structure, environment and performance: The role of strategic choice. Sociology, 6(1), 1-22.

Child, J. (1997). Strategic choice in the analysis of action, structure, organizations and environment: Retrospect and prospect. Organization Studies, 18(1), 43-76.

Choi, J. (2020). Mitigating the challenges of partner knowledge diversity while enhancing Research \& Development (R\&D) alliance performance: The role of alliance governance mechanisms. Journal of Product Innovation Management, 37(1), 26-47.

Cohen, W. M., \& Levinthal, D. A. (1990). Absorptive capacity: A new perspective on learning and innovation. Administrative Science Quarterly, 35(1), 128-152.

Dawson, J. F., \& Richter, A. W. (2006). Probing three-way interactions in moderated multiple regression: Development and application of a slope difference test. Journal of Applied Psychology, 91(4), 917.

Deng, P., \& Zhang, S. (2018). Institutional quality and internationalization of emerging market firms: Focusing on Chinese SMEs. Journal of Business Research, 92, 279-289.

de Leeuw, T., Lokshin, B., \& Duysters, G. (2014). Returns to alliance portfolio diversity: The relative effects of partner diversity on firm's innovative performance and productivity. Journal of Business Research, 67(9), 1839-1849.

Demirbag, M., Glaister, K. W., \& Sengupta, A. (2020). Which regions matter for MNEs? The role of regional and firm level differences. Journal of World Business, 55(1), 101026.

Dickson, P. H., \& Weaver, K. M. (1997). Environmental determinants and individual-level moderators of alliance use. Academy of Management Journal, 40(2), 404-425.

Donbesuur, F., Ampong, G. O. A., Owusu-Yirenkyi, D., \& Chu, I. (2020). Technological innovation, organizational innovation and international performance of SMEs: The moderating role of domestic institutional environment. Technological Forecasting and Social Change, 161, 120252.

Dooley, L., Kenny, B., \& Cronin, M. (2016). Interorganizational innovation across geographic and cognitive boundaries: Does firm size matter? R\&D Management, 46(S1), 227-243.

Dorobantu, S., Lindner, T., \& Müllner, J. (2019). Political risk and alliance diversity: A two-stage model of partner selection in multipartner alliances. Academy of Management Journal, 63(6), 1775-1806.

Drnevich, P. L., \& West, J. (2021). Performance implications of technological uncertainty, age, and size for small businesses. Journal of Small Business Management, 1-36.

Dyer, J. H., \& Singh, H. (1998). The relational view: Cooperative strategy and sources of interorganizational competitive advantage. Academy of Management Review, 23(4), 660-679.

Dyer, J. H., Singh, H., \& Hesterly, W. S. (2018). The relational view revisited: A dynamic perspective on value creation and value capture. Strategic Management Journal, 39(12), 3140-3162.

Feng, T., Wang, D., Lawton, A., \& Luo, B. N. (2019). Customer orientation and firm performance: The joint moderating effects of ethical leadership and competitive intensity. Journal of Business Research, 100, 111-121.

Ferraris, A., Giachino, C., Ciampi, F., \& Couturier, J. (2019). R\&D internationalization in mediumsized firms: The moderating role of knowledge management in enhancing innovation performances. Journal of Business Research, 128, 711-718.

Ferreras-Méndez, J. L., Fernández-Mesa, A., \& Alegre, J. (2019). Export performance in SMEs: The importance of external knowledge search strategies and absorptive capacity. Management International Review, 59(3), 413-437.

Fornell, C., \& Larcker, D. F. (1981). Evaluating structural equation models with unobservable variables and measurement error. Journal of Marketing Research, 18(1), 39-50.

Garcia Martinez, M., Zouaghi, F., \& Sanchez Garcia, M. (2017). Capturing value from alliance portfolio diversity: The mediating role of R\&D human capital in high and low tech industries. Technovation, 59, 55-67.

Grewal, R., \& Tansuhaj, P. (2001). Building organizational capabilities for managing economic crisis: The role of market orientation and strategic flexibility. Journal of Marketing, 65(2), 67-80.

Gulati, R. (1998). Alliances and networks. Strategic Management Journal, 19(4), 293-317. 
Hagedoorn, J., Lokshin, B., \& Zobel, A.-K. (2018). Partner type diversity in alliance portfolios: Multiple dimensions, boundary conditions and firm innovation performance. Journal of Management Studies, 55(5), 809-836.

Hao, B., Ye, J., Feng, Y., \& Cai, Z. (2020). Explicit and tacit synergies between alliance firms and radical innovation: The moderating roles of interfirm technological diversity and environmental technological dynamism. R\&D Management, 50(4), 432-446.

He, C., Baranchenko, Y., Lin, Z., Szarucki, M., \& Yukhanaev, A. (2020). From global mindset to international opportunities: The internationalization of Chinese SMEs. Journal of Business Economics and Management, 21(4), 967-986.

Hennart, J. F., Majocchi, A., \& Forlani, E. (2019). The myth of the stay-at-home family firm: How family-managed SMEs can overcome their internationalization limitations. Journal of International Business Studies, 50(5), 758-782.

Heirati, N., O'Cass, A., Schoefer, K., \& Siahtiri, V. (2016). Do professional service firms benefit from customer and supplier collaborations in competitive, turbulent environments? Industrial Marketing Management, 55, 50-58.

Hervas-Oliver, J.-L., Ripoll-Sempere, F., \& Moll, C. B. (2016). Does management innovation pay-off in SMEs? Empirical evidence for Spanish SMEs. Small Business Economics, 47(2), 507-533.

Hitt, M. A., Hoskisson, R. E., \& Ireland, R. D. (1994). A mid-range theory of the interactive effects of international and product diversification on innovation and performance. Journal of Management, 20(2), 297-326.

Ho, M. H. W., Ghauri, P. N., \& Kafouros, M. (2019). Knowledge acquisition in international strategic alliances: The role of knowledge ambiguity. Management International Review, 59(3), 439-463.

Hock-Doepgen, M., Clauss, T., Kraus, S., \& Cheng, C. F. (2021). Knowledge management capabilities and organizational risk-taking for business model innovation in SMEs. Journal of Business Research, 130, 683-697.

Hung, K.-P., \& Chou, C. (2013). The impact of open innovation on firm performance: The moderating effects of internal R\&D and environmental turbulence. Technovation, 33(10), 368-380.

Huo, B., Ye, Y., Zhao, X., Wei, J., \& Hua, Z. (2018). Environmental uncertainty, specific assets, and opportunism in 3PL relationships: A transaction cost economics perspective. International Journal of Production Economics, 203, 154-163.

Idris, B., \& Saridakis, G. (2018). Local formal interpersonal networks and SMEs internationalisation: Empirical evidence from the UK. International Business Review, 27(3), 610-624.

Irfan, M., Wang, M., \& Akhtar, N. (2019). Impact of IT capabilities on supply chain capabilities and organizational agility: A dynamic capability view. Operations Management Research, 12(3), $113-128$.

Iurkov, V., \& Benito, G. R. G. (2018). Domestic alliance networks and regional strategies of MNEs: A structural embeddedness perspective. Journal of International Business Studies, 49(8), 1033-1059.

Iurkov, V., \& Benito, G. R. (2020). Change in domestic network centrality, uncertainty, and the foreign divestment decisions of firms. Journal of International Business Studies, 51(5), 788-812.

Jaworski, B. J., \& Kohli, A. K. (1993). Market orientation: Antecedents and consequences. Journal of Marketing, 57(3), 53-70.

Kano, L., Tsang, E. W., \& Yeung, H. W. C. (2020). Global value chains: A review of the multi-disciplinary literature. Journal of International Business Studies, 51(4), 577-622.

Khan, H. (2020). Is marketing agility important for emerging market firms in advanced markets?. International Business Review, 29(5), 101733.

Khan, Z., Amankwah-Amoah, J., Lew, Y. K., Puthusserry, P. and Czinkota, M., 2020. Strategic ambidexterity and its performance implications for emerging economies multinationals. International Business Review, 101762.

Khan, Z., \& Lew, Y. K. (2018). Post-entry survival of developing economy international new ventures: A dynamic capability perspective. International Business Review, 27(1), 149-160.

Khan, Z., Rao-Nicholson, R., \& Tarba, S. Y. (2018). Global networks as a mode of balance for exploratory innovations in a late liberalizing economy. Journal of World Business, 53(3), 392-402.

Kline, R. B. (2015). Principles and practice of structural equation modeling. Guilford publications.

Kok, H., Faems, D., \& de Faria, P. (2020). Ties that matter: The impact of alliance partner knowledge recombination novelty on knowledge utilization in R\&D alliances. Research Policy, 49(7), 104011.

Kwok, F., Sharma, P., Gaur, S. S., \& Ueno, A. (2019). Interactive effects of information exchange, relationship capital and environmental uncertainty on international joint venture (IJV) performance: An emerging markets perspective. International Business Review, 28(5), 101481. 
Lavie, D. (2007). Alliance portfolios and firm performance: A study of value creation and appropriation in the US software industry. Strategic Management Journal, 28(12), 1187-1212.

Li, L., Qian, G., \& Qian, Z. (2013). Do partners in international strategic alliances share resources, costs, and risks? Journal of Business Research, 66(4), 489-498.

Lii, P., \& Kuo, F.-I. (2016). Innovation-oriented supply chain integration for combined competitiveness and firm performance. International Journal of Production Economics, 174, 142-155.

Li, C., \& Reuer, J.J., 2021. The impact of corruption on market reactions to international strategic alliances. Journal of International Business Studies, 1-16.

Lin, F.-J., \& Lin, Y.-H. (2016). The effect of network relationship on the performance of SMEs. Journal of Business Research, 69(5), 1780-1784.

Love, J. H., Roper, S., \& Zhou, Y. (2016). Experience, age and exporting performance in UK SMEs. International Business Review, 25(4), 806-819.

Marhold, K., \& Kang, J. (2017). The effects of internal technological diversity and external uncertainty on technological alliance portfolio diversity. Industry and Innovation, 24(2), 122-142.

Martineau, C., \& Pastoriza, D. (2016). International involvement of established SMEs: A systematic review of antecedents, outcomes and moderators. International Business Review, 25(2), 458-470.

Martinez, M. G., Zouaghi, F., \& Garcia, M. S. (2017). Capturing value from alliance portfolio diversity: The mediating role of R\&D human capital in high and low tech industries. Technovation, 59, 55-67.

Mohr, A., Wang, C., \& Goerzen, A. (2016). The impact of partner diversity within multiparty international joint ventures. International Business Review, 25(4), 883-894.

Mueller-Using, S., Urban, W., \& Wedemeier, J. (2020). Internationalization of SMEs in the Baltic Sea Region: Barriers of cross-national collaboration considering regional innovation strategies for smart specialization. Growth and Change, 51(4), 1471-1490.

Musteen, M., Datta, D. K., \& Butts, M. M. (2014a). Do international networks and foreign market knowledge facilitate SME internationalization? Evidence from the Czech Republic. Entrepreneurship Theory and Practice, 38(4), 749-774.

Musteen, M., Datta, D. K., \& Francis, J. (2014b). Early internationalization by firms in transition economies into developed markets: The role of international networks. Global Strategy Journal, 4(3), 221-237.

Nakos, G., Brouthers, K. D., \& Dimitratos, P. (2014). International alliances with competitors and noncompetitors: The disparate impact on SME international performance. Strategic Entrepreneurship Journal, 8(2), 167-182.

Nakos, G., Dimitratos, P., \& Elbanna, S. (2019). The mediating role of alliances in the international market orientation-performance relationship of SMEs. International Business Review, 28(3), 603-612.

Nguyen, A., \& Özçaglar-Toulouse, N. (2021). Nation branding as a market-shaping strategy: A study on South Korean products in Vietnam. Journal of Business Research, 122, 131-144.

Nyamrunda, F.C., \& Freeman, S. (2021). Strategic agility, dynamic relational capability and trust among SMEs in transitional economies. Journal of World Business, 56(3), p.101175.

O'Dwyer, M., \& Gilmore, A. (2018). Value and alliance capability and the formation of strategic alliances in SMEs: The impact of customer orientation and resource optimisation. Journal of Business Research, 87, 58-68.

Oerlemans, L. A., Knoben, J., \& Pretorius, M. W. (2013). Alliance portfolio diversity, radical and incremental innovation: The moderating role of technology management. Technovation, 33(6-7), 234-246.

Oura, M. M., Zilber, S. N., \& Lopes, E. L. (2016). Innovation capacity, international experience and export performance of SMEs in Brazil. International Business Review, 25(4), 921-932.

Osei, C., Amankwah-Amoah, J., Khan, Z., Omar, M., \& Gutu, M. (2019). Developing and deploying marketing agility in an emerging economy: The case of Blue Skies. International Marketing Review, 36(2), 190-212.

Packard, M. D., Clark, B. B., \& Klein, P. G. (2017). Uncertainty types and transitions in the entrepreneurial process. Organization Science, 28(5), 840-856.

Peng, X. B., Liu, Y. L., Jiao, Q. Q., Feng, X. B., \& Zheng, B. (2020). The nonlinear effect of effectuation and causation on new venture performance: The moderating effect of environmental uncertainty. Journal of Business Research, 117, 112-123.

Pervan, S., Al-Ansaari, Y., \& Xu, J. (2015). Environmental determinants of open innovation in Dubai SMEs. Industrial Marketing Management, 50, 60-68. 
Pesch, R., \& Bouncken, R. B. (2018). How to achieve benefits from diversity in international alliances: Mechanisms and cultural intelligence. Global Strategy Journal, 8(2), 275-300.

Pisani, N., Caldart, A., \& Hopma, J. (2017). SMEs' formation of minority international joint ventures and level of internationalization: The moderating role of a global versus regional focus. European Management Journal, 35(3), 414-424.

Podsakoff, P. M., MacKenzie, S. B., Lee, J. Y., \& Podsakoff, N. P. (2003). Common method biases in behavioral research: A critical review of the literature and recommended remedies. Journal of Applied Psychology, 885(879), 10-37.

Popa, S., Soto-Acosta, P., \& Martinez-Conesa, I. (2017). Antecedents, moderators, and outcomes of innovation climate and open innovation: An empirical study in SMEs. Technological Forecasting and Social Change, 118, 134-142.

Rahman, M., Rodríguez-Serrano, M. Á., \& Hughes, M. (2020). Does advertising productivity affect organizational performance? Impact of market conditions. British Journal of Management, ahead of print.

Robson, M. J., Katsikeas, C. S., Schlegelmilch, B. B., \& Pramböck, B. (2019). Alliance capabilities, interpartner attributes, and performance outcomes in international strategic alliances. Journal of World Business, 54(2), 137-153.

Santoro, M. D., \& McGill, J. P. (2005). The effect of uncertainty and asset co-specialization on governance in biotechnology alliances. Strategic Management Journal, 26(13), 1261-1269.

Sakhdari, K., Burgers, J. H., \& Davidsson, P. (2020). Alliance portfolio management capabilities, corporate entrepreneurship, and relative firm performance in SMEs. Journal of Small Business Management, 1-29.

Shah, S. H., Ahmad, M. H., \& Ahmed, Q. M. (2016). The nexus between sectoral FDI and institutional quality: Empirical evidence from Pakistan. Applied Economics, 48(17), 1591-1601.

Shams, R., Vrontis, D., Belyaeva, Z., Ferraris, A., \& Czinkota, M.R., 2021. Strategic agility in international business: A conceptual framework for "agile" multinationals. Journal of International Management, 27(1), p.100737.

Shijaku, E., Larraza-Kintana, M., \& Urtasun-Alonso, A. (2020). Network centrality and organizational aspirations: A behavioral interaction in the context of international strategic alliances. Journal of International Business Studies, 51(5), 813-828.

Shin, H., Lee, J. N., Kim, D., \& Rhim, H. (2015). Strategic agility of Korean small and medium enterprises and its influence on operational and firm performance. International Journal of Production Economics, 168, 181-196.

Sinkovics, N., Choksy, U. S., Sinkovics, R. R., \& Mudambi, R. (2019). Knowledge connectivity in an adverse context: Global value chains and Pakistani offshore service providers. Management International Review, 59(1), 131-170.

Solheim, M. C. W. (2016). Foreign workers and international partners as channels to international markets in core, intermediate and peripheral regions. Regional Studies, Regional Science, 3(1), 491-505.

Stoian, M.-C., Dimitratos, P., \& Plakoyiannaki, E. (2018). SME internationalization beyond exporting: A knowledge-based perspective across managers and advisers. Journal of World Business, 53(5), 768-779.

Stouraitis, V., Harun, M. H. M., \& Kyritsis, M. (2017). Motivators of SME initial export choice and the European Union regional effect in manufacturing. International Journal of Entrepreneurial Behavior \& Research, 23(1), 35-55.

Su, Z., Ahlstrom, D., Li, J., \& Cheng, D. (2013). Knowledge creation capability, absorptive capacity, and product innovativeness. $R \& D$ Management, 43(5), 473-485.

Subramanian, A. M., \& Soh, P.-H. (2017). Linking alliance portfolios to recombinant innovation: The combined effects of diversity and alliance experience. Long Range Planning, 50(5), 636-652.

Sun, J., Maksimov, V., Wang, S. L., \& Luo, Y. (2021). Developing compositional capability in emerging-market SMEs. Journal of World Business, 56(3), 101148.

Teece, D. J. (2007). Explicating dynamic capabilities: The nature and microfoundations of (sustainable) enterprise performance. Strategic Management Journal, 28(13), 1319-1350.

Teece, D., Peteraf, M., \& Leih, S. (2016). Dynamic capabilities and organizational agility: Risk, uncertainty, and strategy in the innovation economy. California Management Review, 58(4), $13-35$. 
Torkkeli, L., Kuivalainen, O., Saarenketo, S., \& Puumalainen, K. (2019). Institutional environment and network competence in successful SME internationalisation. International Marketing Review, 36(1), 31-55.

Tower, A. P., Hewett, K., \& Saboo, A. (2021). Reexamining the tradeoff between value creation and value appropriation: The role of internal organizational resources vs. External strategic international alliances. Journal of Business Research, 123, 302-312.

Trading Economics. (2020). Pakistan GDP Annual Growth Rate. Available ONLIE from, https://tradi ngeconomics.com/pakistan/gdp-growth-annual

Turkina, E., \& Van Assche, A. (2018). Global connectedness and local innovation in industrial clusters. Journal of International Business Studies, 49(6), 706-728.

Uddin, M., Chowdhury, A., Zafar, S., Shafique, S., \& Liu, J. (2019). Institutional determinants of inward FDI: Evidence from Pakistan. International Business Review, 28(2), 344-358.

Vadakkepatt, G., Shankar, V., \& Varadarajan, R. (2021). Should firms invest more in marketing or R\&D to maintain sales leadership? An empirical analysis of sales leader firms. Journal of the Academy of Marketing Science, 1-21.

Verbeke, A., \& Asmussen, C. G. (2016). Global, local, or regional? The locus of MNE strategies. Journal of Management Studies, 53(6), 1051-1075.

Vlaisavljevic, V., Cabello-Medina, C., \& Pérez-Luño, A. (2016). Coping with diversity in alliances for innovation: The role of relational social capital and knowledge codifiability. British Journal of Management, 27(2), 304-322.

Wang, S., \& Chin, T., 2020. A stratified system of knowledge and knowledge icebergs in cross-cultural business models: Synthesising ontological and epistemological views. Journal of International Management, 26(4), p.100780.

Wang, C. L., \& Chung, H. F. (2020). Business networking and innovation of Asian enterprises in Western countries: The moderation of institutional distance. Industrial Marketing Management, 88, $152-162$.

Wu, B., \& Deng, P. (2020). Internationalization of SMEs from emerging markets: An institutional escape perspective. Journal of Business Research, 108, 337-350.

Yiu, D. W., Lau, C., \& Bruton, G. D. (2007). International venturing by emerging economy firms: The effects of firm capabilities, home country networks, and corporate entrepreneurship. Journal of International Business Studies, 38(4), 519-540.

Yu, A., Lumpkin, G. T., Praveen Parboteeah, K., \& Stambaugh, J. E. (2019). Autonomy and family business performance: The joint effect of environmental dynamism and national culture. International Small Business Journal, 37(2), 153-185.

Zahoor, N., Al-Tabbaa, O., Khan, Z., \& Wood, G. (2020). Collaboration and internationalization of SMEs: Insights and recommendations from a systematic review. International Journal of Management Reviews, 22(4), 427-456.

Zahoor, N., \& Al-Tabbaa, O. (2021). Post-entry internationalization speed of SMEs: The role of relational mechanisms and foreign market knowledge. International Business Review, 30(1), 101761.

Zahoor, N., Khan, Z., Arslan, A., Khan, H., \& Tarba, S. Y. (2021). International open innovation and international market success: an empirical study of emerging market small and medium-sized enterprises. International Marketing Review, ahead of print.

Zahoor, N., \& Lew, Y. K. (2021). The drivers of the post-entry internationalisation commitment of small and medium-sized enterprises. International Small Business Journal, ahead of print.

Zahra, S. A. (2020). Technological capabilities and international expansion: The moderating role of family and non-family firms' social capital. Asia Pacific Journal of Management, 37(2), 391-415.

Zahra, S. A., \& George, G. (2002). Absorptive capacity: A review, reconceptualization, and extension. Academy of Management Review, 27(2), 185-203.

Zahra, S. A., Neubaum, D. O., \& Huse, M. (2000). Entrepreneurship in medium-size companies: Exploring the effects of ownership and governance systems. Journal of Management, 26(5), 947-976.

Zhang, Y., Liu, S., Tan, J., Jiang, G., \& Zhu, Q. (2018). Effects of risks on the performance of business process outsourcing projects: The moderating roles of knowledge management capabilities. International Journal of Project Management, 36(4), 627-639.

Publisher's note Springer Nature remains neutral with regard to jurisdictional claims in published maps and institutional affiliations. 
Nadia Zahoor is a Lecturer at the University of Strathclyde, UK. She completed her PhD in Management at University of Huddersfield, UK. Her research interests are on strategic alliances, global strategy, innovation, and organizational resilience. She is particularly interested in the context of small and mediumsized enterprises in emerging markets. Her research has been published in mainstream journals, including International Journal of Management Reviews, International Business Review, Business Strategy and the Environment, Scandinavian Journal of Management, among others.

Francis Donbesuur is a Lecturer in International Business, Strategy and Innovation at the Loughborough University, United Kingdom. His research focuses on the interface between international entrepreneurship, innovation and strategy. He completed his $\mathrm{PhD}$ in Strategic Entrepreneurship from the University of Leeds, United IKingdom and an MSc. in Economics and Finance from Durham University, United Kingdom. His research has been published in some leading Journals including the Journal of Business Research, Journal of Psychology and Marketing, Management International Review, Journal of International Management, among others.

Arinze Christian Nwoba is a Lecturer in Marketing and Marketing Communications at the University of Greenwich, United Kingdom. His research focuses on the interface between organisational sustainability strategies, managerial networking relationship, emerging market strategies and market performance. $\mathrm{He}$ holds a BSc in Economics and an MSc in Management as well as a PhD in Strategic Marketing Management from the University of Leeds, United Kingdom. He has presented his on-going research works at renowned international marketing and management conferences. His research has been published in Business Strategy and the Environment journal.

Huda Khan is a Senior Lecturer in Marketing and Associate Director of Africa Asia Centre of Sustainability Research at the University of Aberdeen, UK. Prior to joining University of Aberdeen, Huda has worked on a wide range of industry-led research projects with Ehrenberg-Bass Institute of Marketing Science (EBI) in Australia, a world class market research centre. As a Marketing Scientist with EBI, she has worked on consultancy projects involving well-known multinational corporations such as Unilever and SC Johnsons. These projects (worth $>\$ 100,000$ ) involved research in a number of markets including the United Kingdom, the United States, Norway, Argentina, Brazil, China, Germany and France. Her research focuses on dynamic marketing capabilities of emerging market firms in advanced markets and competition between multinational firms from advanced and emerging markets when they enter into each other's market. Huda's research has appeared in leading journals including International Business Review and Annals of Tourism journals, among others. 